\title{
LEGAL MAINTENANCE OF LABOUR MARKET IN SPECIAL SECTORS OF RUSSIA'S INDUSTRY IN THE LATE XIX - EARLY XX CENTURIES
}

(C) 2017

\author{
Volkov Yyacheslav Victorovich, candidate of philosophical sciences, associate professor, \\ senior lecturer of Humanities and Social Sciences Department \\ Military-Transport Institute (Railroad Troops) of Military Academy of Logistics \\ named after Army General A.V. Khrulev (Saint Petersburg, Russian Federation)
}

\begin{abstract}
The paper examines a legal aspect of the hiring of workers in special sectors of Russia's industry in the late XIX - early XX centuries. The conclusion is that the adopted factory laws put some grounds of contract law in the framework of mutual relations of workers and employers, with many exemptions, however, which excluded the equality of the contracting parties. Unlike Western countries the trend subordination of all categories of workers to general labour legislation was less in Russia. General factory laws originally concerned only enterprises of Ministry of Finance. Railway, construction, shipping workers, workers of military enterprises remained outside the subordination of the Charter of the industry. In other government departments there was its own legal framework regulating the employment relationship. Employment and work conditions were better in the Navy and worse in enterprises of the Ministry of Railways. The Mining department made big progress in the development of labor legislation. It limited the advance recruitment, hired well-organized cooperatives, banned the labor of women and children at night, it limited a working day to eight hours, established direct material plant responsible for the accuracy of the contractor in the payment of workers' wages, allowed the establishment of special mining and metallurgical associations (partnerships). In general the legal maintenance of labour market in special sectors of Russian industry in the late XIX early XX centuries was more organized and had better workers' social protection than the main industry of Russia.

Keywords: law; workers; hiring; factory inspection; contract; special sectors; legal support; working conditions; factory; legal acts; Russia; article; department; paybook; labor legislation; industry; working day; cooperative society; fine; Charter of industry; mining Charter.
\end{abstract}

УДК 94(47).084.8

\section{К ВОПРОСУ О СТАНОВЛЕНИИ ТРАМВАЙНОГО ДВИЖЕНИЯ В Г. УЛЬЯНОВСКЕ} (C) 2017

Горшенин Александр Владимирович, старший преподаватель кафедры гуманитарных дисциплин Медичинский университет «Реавиз» (2. Самара, Российская Федерачия)

Аннотация. В статье рассматривается процесс становления общественного транспорта Ульяновска. Особое внимание уделено проектам строительства трамвая, которые существовали в дореволюционный период, а также приведены условия их реализации и планы воплощения. Устанавливается связь между административным статусом города и развитием в нём общественного транспорта. Когда в 1920-е годы Ульяновск лишился статуса губернского центра, то надолго были отложены попытки организовать в городе линию электротранспорта. Только в годы Великой Отечественной войны, когда Ульяновск стал центром вновь образованной области, власти решились на создание в городе трамвая. Рассматривая этапы становления трамвайного транспорта, делаются попытки определить причины, которые приводили к задержке строительных работ. Основными из них явились следующие: недостаточное финансирование, затянувшееся оформление всей необходимой документации, отсутствие в городе соответствующей материально-технической базы и квалифицированных работников. В данной публикации изучаются мероприятия, которые проводились для устранения названных проблем.

Источниковой базой исследования послужили неопубликованные документы из фондов федеральных и региональных архивов - Государственного архива Российской Федерации, Российского государственного архива экономики, филиала Российского государственного архива научно-технической документации, Государственного архива Ульяновской области, Государственного архива новейшей истории Ульяновской области. Также в публикации используются материалы местной периодической печати рассматриваемых лет областной газеты «Ульяновская правда».

Ключевые слова: городской транспорт; общественный транспорт; электрический транспорт; трамваи; городское хозяйство; коммунальное хозяйство; уличное движение; Ульяновск; Симбирск; экономика; история; региональная история; история повседневности; Великая Отечественная война; послевоенный период.

Через призму развития общественного транспорта можно проследить важнейшие стороны социально-экономического развития региона. В ходе урабанизационных процессов 1930-х гг., связанных с индустриализацией, происходит расширение городов, в связи с чем значительно возрастает роль внутригородского транспорта, обеспечивающего взаимодействие различных компонентов городского хозяйства и объединяющего их в единую систему.
Историографию указанной проблемы следует разделить на два периода: советский и постсоветский. Для исследований советской эпохи характерным является минимальный интерес к теме истории общественного транспорта и практически полное отсутствие специальных исследований. В основном данные вопросы изучались в контексте жилищнокоммунального хозяйства в изданиях общего характера [1]. В постсоветский период появляются рабо- 
ты, освещавшие историю становления и развития общественного транспорта [2;3].

Формирование иелей статьи (постановка задания). В ходе исследования, опираясь на широкую документальную базу, необходимо рассмотреть процесс становления трамвайного транспорта Ульяновска. Для этого следует изучить дореволюционные проекты строительства трамвая и выяснить, по какой причине они не реализовались. Стоит понять, как сыграл фактор смены административного статуса города на реализацию данных мероприятий. Основной целью работы является изучение основных этапов планирования, строительства, вводу в эксплуатацию трамвая г. Ульяновска и установление причин затянувшегося строительства.

Симбирск (так до 1924 г. назывался Ульяновск) начала XX в. - это довольно неблагоустроенный город: грунтовые дороги многих центральных улиц находились в ужасном состоянии, по ним часто невозможно было проехать не только в весеннюю или осеннюю распутицу, но и в другие времена года. Из 7,3 тыс. верст общей протяженности дорог губернии замощенные участки составляли лишь 25 верст, шоссированные - 40 [4, с. 12].

Впервые обсуждение по поводу строительства в городе трамвая началось ещё в самом начале XX в.

В 1901 г. городская Управа рассматривала доклад городского головы М.А. Волкова об устройстве в г. Симбирске работающих на электричестве элеватора для подъема тяжестей и пассажиров с пристаней на р. Волга в город, трамвая по городу и освещения. Ознакомившись со всеми предложениями и выводами городского головы, изложенными в его докладе, Управа согласилась принять доклад Волкова и, сообщая городской Думе об этом, настаивала сделать предложение о реализации этого проекта концессионным способом всем русским и заграничным предпринимателям [5, с. 1].

Городской голова в своём докладе рассмотрел условия устройства электрического трамвая и освещения в Тамбове, Смоленске, Царицыне и Костроме, после чего пришёл к выводу, что одновременная отдача в эксплуатацию обоих предприятий в одни и те же руки является более выгодной как для городов, так и для предпринимателей [5, с. 23].

При обсуждении вопроса об устройстве трамвая, говоря о необходимости этого мероприятия, М.А. Волков приводил пример, что сообщение города с пристанью стоит столько же, сколько и билет в третьем классе до Самары. А Смоленский спуск к пристани, взобраться на который составляет для рабочего и приходящего на рынки окрестного населения сущий подвиг, сопряженный с огромной затратой сил и времени [5, с. 24].

Согласно разработанному проекту, г. Симбирск предоставлял предпринимателю право устроить и эксплуатировать за его счет, риск и страх в городе следующие электрические предприятия:

a) самотаску (элеватор) от пристаней по горе для перевозки лесных материалов, грузов и пассажиров, с полным оборудованием и подвижным составом;

б) электрическую железную дорогу «трамвай» с подвижным составом и всеми принадлежностями эксплуатации для перевозки по городу пассажиров и грузов; в) электрическое освещение для улиц, казенных, частных и общественных зданий, снабжения двигательной силой промышленных предприятий и для всех других целей, со всеми сооружениями и приспособлениями для удовлетворительной эксплуатации $[5$, с. 35$]$.

Эксплуатацию всех сооружений предполагалось предоставить на 30 лет с обязательством со стороны города в течение всего этого срока никому не разрешать прокладывать рельсовые пути по городу.

В первую очередь в течение полутора лет предприниматель должен был устроить электрический трамвай по следующим улицам: от вокзала железной дороги до Сызранской улицы, затем по Александровской площади, Театральной, Большой Саратовской, Старо-Казанской и Смоленской улицам до элеватора. Подъёмный элеватор необходимо было построить в этот же срок от пристани по Смоленскому спуску или около казарм инженерного ведомства до Смоленской улицы, где должен находиться приёмный павильон для пассажиров. Стоит обратить внимание, что линии трамвая и элеватора должны были примыкать друг к другу так, чтобы по ним могло производиться непрерывное движение и чтобы при пересадках с одного пути на другой пассажир проходил расстояние не более 3 сажен и не иначе, как в крытом павильоне. В последующие пять лет предполагалось создание разветвлённой трамвайной сети и элеватора для перевозки грузов [5, с. 36-37].

Интервал движения вагонов на линии планировался в среднем 10 минут, а средняя скорость пассажирского движения - 12 верст в час. Пассажирское движение вагонов задумывалось организовать в летний период - с 5 часов утра до 11 часов вечера, а в зимний - с 7 часов утра до 9 часов вечера. Причём движение товарных вагонов осуществлялось бы днём и ночью, но чтобы оно не мешало движению пассажирских вагонов [5, с. 40].

Ввиду отсутствия предпринимателей, желавших вложить средства в строительство симбирского трамвая, а также начавшейся Первой русской революции проект так и не был реализован.

К вопросу о необходимости строительства трамвая вновь вернулись на заседании Городской думы в ноябре 1910 г. Первая линия должна была соединить пристани на Волге с городом. Причём предполагалось, что трамваи будут перевозить не только пассажиров, но и грузы. Разработка данного вопроса затянулась на два года.

В 1912 г. первый маршрут был окончательно утверждён [6, л. 31]. Он состоял из трёх линий: Вокзальной, Подгорной и Спасской. Скорость движения вагонов предполагалась от 10 до 15 верст в час, предлагаемый маршрут ложился на сформированную сетку улиц и почти не требовал планировки. Предлагалось закупить 20 вагонов. Вопрос снабжения линии электрической энергией решался в расчёте на строящуюся в то время электростанцию мощностью в 530 киловатт. Московским инженерам Сушкину, Авенариусу поручили разработать эскизный проект устройства электрического трамвая. К августу проект был завершён, а в 1914 г. Городская дума одобрила план. Строительство предполагалось вести на условиях займа, погашение которого рассчитывалось на 49 лет [7, с. 13]. Но начавшаяся Первая мировая война не позволила воплотить этот план в жизнь. 
К вопросу строительства трамвая в Симбирске вернулись в 1918 г. За основу взяли проект 1914 г., куда внесли некоторые изменения: предполагалось сооружение трёх дополнительных трамвайных линий и увеличение трамвайного парка до 33 вагонов. Кроме того, дополнения к первоначальному проекту предусматривали также введение 31 прицепного вагона и сооружение снегоочистителя, а для ремонта проводов - башенной повозки. Проект и смета прошли рассмотрение в Москве, где идея постройки трамвая с точки зрения развития города была единодушно признана необходимой, но пока невозможной, в силу кризиса промышленности. К тому же началась Гражданская война, которая в очередной раз отложила реализацию рассматриваемого проекта [4, c. 15].

В 1928 г. Ульяновская губерния вошла в состав Средневолжской области и до 1943 г. Ульяновск был окружным, а затем и районным центром. Понижение административного статуса отложило на долгие годы вопрос строительства линии электротранспорта.

В годы Великой Отечественной войны сюда эвакуируются многие предприятия с западных рубежей страны. Началось строительство автомобильного завода, были пущены заводы приборостроительный и «Контактор», трикотажная фабрика имени КИМ и другие предприятия [8, с. 22].

В связи с увеличением города и числа предприятий в январе 1943 г. из Куйбышевской области была выделена Ульяновская. Ульяновск, став областным центром, насчитывал свыше 150 тыс. жителей [9, c. 23].

Из общественного транспорта в городе существовало лишь автобусное сообщение, да и оно находилось в крайне запущенном состоянии. По этой причине городские власти решили организовать в городе трамвайное сообщение. Для этого Ульяновском был заключён договор с московской проектно-изыскательской конторой «Дортранспроект» на планировку трамвайной линии и тяговой подстанции [10, л. 12].

Собственными силами местным властям Ульяновска не удалось осуществить этот проект. Поэтому решением данного вопроса занялись высшие органы власти. Так, уже в октябре 1944 г. СНК СССР выпускает постановление «О мероприятиях по улучшению городского хозяйства Ульяновска» $[11$, л. 200], по которому в 1945 г. предусматривалось начать строительство первой очереди трамвая от Волжской пристани до строительной площадки Ульяновского автомобильного завода им. Сталина. Предполагалось уложить одиночный путь протяжённостью 7 км и ввести его в эксплуатацию в III квартале 1945 г. [12, л. 26].

При этом СНК СССР обязал Наркомат коммунального хозяйства РСФСР до 1 декабря 1944 г. разработать предварительный проект постройки этой первой очереди трамвая [12, л. 28], а до 1 марта 1945 г. окончательно закончить технический проект [13, л. 21].

Трамвайная линия, согласно данному проекту, должна была связать внутригородским транспортом центральную часть города с развивающимися промышленными районами Ульяновска - в Засвияжье автомобильным заводом, в южной части - заводом малолитражных двигателей, железнодорожной станцией Ульяновск-I с северной частью города.
Кроме этого, создание трамвайной линии предусматривало строительство целого ряда искусственных сооружений, для чего нужно было привлекать сторонние организации. На участке пути следования трамвая из центра города на юг к заводу малолитражных двигателей необходимо было достроить путепровод на возведённых опорах. А на линии, связывающей центр города с Засвияжским районом и автозаводом, требовалось построить дамбу с мостом через р. Свиягу по оси центральной магистрали Засвияжского района [14, л. 38].

В 1945 г. в Ульяновске были завершены проектное задание и техно-рабочий проект моста через р. Свиягу и деревянного путепровода, необходимых для начала строительства транспортной линии [15, л. 16].

Несмотря на постановление СНК СССР, в котором указывались чёткие сроки составления чертежей и начала строительства трамвая, проект Ульяновского трамвая первой очереди был рассмотрен и утверждён Министерством коммунального хозяйства РСФСР с большим опозданием, только в 1946 г. [14, л. 37].

Ульяновский городской отдел коммунального хозяйства, в свою очередь, сумел заключить договор с конторой «Дортранспроект» на проектирование трамвайной линии, депо, вагоноремонтной мастерской на 50 вагонов и тяговой подстанции ещё 9 января 1945 г. [15, л. 31]. Сметная стоимость проекта составила 10,47 млн. руб. [14, л. 37].

10 декабря 1945 г. городские власти направили в СНК РСФСР письмо «О строительстве трамвая в г. Ульяновске в 1946 г.», в котором излагалась необходимость скорейшего строительства электротранспорта и прилагался технический проект со сметой. Данное письмо было рассмотрено Народным комиссариатом коммунального хозяйства РСФСР. Оказалось, что для строительства трамвая в г. Ульяновске на 1946 г. были запланированы капиталовложения в размере 500 тыс. руб.

Но в Госплане СССР при рассмотрении капиталовложений по коммунальным предприятиям РСФСР на этот год средства на строительство трамвая в г. Ульяновске сняли, ввиду отсутствия перспектив на получение фондов на основные строительные материалы и оборудование (рельсы, шпалы, цемент и др.). В результате строительство трамвая в г. Ульяновске из плана 1946 г. исключалось [16, л. 10]. Таким образом, начало строительства опять откладывалось.

А в конце 1946 г. появилась другая причина для того, чтобы в очередной раз перенести сроки начала строительства. В этом году специалисты «Дортранспроекта» установили, что район волжской пристани подвержен оползням. В связи с этим Ульяновский горисполком вынужден был наметить новую трассу, связывающую автомобильно-дизельный завод с центром и с Северным районом города $[17$, л. 218]. Изменение трассы повлекло за собой необходимость изменения технического проекта и согласования его со всеми инстанциями.

Только спустя почти два года, 24 мая 1948 г., на заседании исполкома Ульяновского городского совета депутатов трудящихся приняли окончательное решение «Об установлении трассы трамвая первой 
очереди строительства и определении мест трамвайного парка и тяговой подстанции». При городском коммунальном отделе организовали дирекцию строящегося трамвая во главе с А.Я. Авилкиным.

На 1949 г. Советом Министров РСФСР было предусмотрено затратить на строительство трамвая 700 тыс. руб., а на 1950 г. - уже 5 млн. руб. При этом часть этой суммы шла за счёт долевого участия министерств вооружения и электропромышленности [18, л. 16].

Стоит подробнее остановиться на долевом участии различных министерств в строительстве трамвайной трассы. Основное количество поездок на проектируемом трамвае должны были совершать рабочие заводов ЗИС (завода им. Сталина), ЗМД (завода малолитражных двигателей), № 230, 10, 65 и завода им. Володарского [7, л. 31 об.]. Поэтому затраты на строительство распределялись между теми ведомствами, в чьём ведении находились данные заводы, а именно между следующими министерствами: автотракторной промышленности, вооружения, авиационной промышленности, электропромышленности и коммунального хозяйства.

В мае 1949 г. Совет Министров СССР утвердил долгосрочный проект планировки и застройки г. Ульяновска. Он предполагал в течение нескольких лет связать центра города с автомобильным заводом, железнодорожным вокзалом и с северным жилым районом трамвайным сообщением [19, л. 68].

В северной части города намечалось строительство трамвайного парка, стоимость которого составляла 3 млн. руб. А вот организация путевого и воздушного хозяйства трамвая протяжённостью 12 км оценивалась в 3,6 млн. руб. [19, л. 34].

Работы осложнялись тем обстоятельством, что проектная организация затягивала с передачей всех проектных документов строительным организациям. Так, в июле 1949 г. в Ульяновск из Москвы приезжал представитель проектной организации «Дортранспроект», который ознакомился с положением дел на месте и заверил городской комитет коммунального хозяйства, что проектировщики и изыскатели приедут в июле и привезут договор с соответствующей документацией. Но, в связи с уменьшением финансирования, бригада смогла приехать только осенью, оттянув, таким образом, начало строительства ещё на несколько месяцев [20, л. 85].

Помимо документации, сложности существовали и с материалами. Полученные в сентябре шпалы не были готовы к укладке. Балласта завезли всего 500 м$^{3}$. Распиловка леса производилась на прирельсовой лесораме ст. Ульяновск-І. Металлические конструкции изготавливались на месте кустарным способом. Затрудняло строительство и отсутствие в Ульяновске асфальтобетонного завода [21, л. 32].

Только 12 ноября 1949 г. на коммунистическом субботнике в районе вокзала станции Ульяновск-I были уложены первые 600 м рельсов трамвайных линий. Право забить первый костыль предоставили передовикам-путейцам - Миронычеву, Вашурову и Андрееву [22, с. 3]. А к 1 декабря 1949 г. успели уложить 1,6 км трамвайных путей [18, л. 17].

В 1950 г. на строительство трамвая из бюджета города отпускалось 812 тыс. руб. В общей сложности за этот год необходимо было использовать 2986 тыс. руб., а израсходовано лишь 741,2 тыс. руб., что составляло примерно 25\%. Невыполнение плана можно объяснить слабой работой треста «Ульяновскстрой», его неприспособленностью выполнять специфические работы, особенно в первоначальный период. Прокладку эксплуатационных путей задерживало отсутствие подкладок. Также плохо поступало оборудование для тяговой подстанции: привезли лишь трансформаторы и ртутные выпрямители [23, л. 33].

Население г. Ульяновска росло и остро нуждалось в организации трамвайного сообщения. Численность жителей города за десятилетие возросла в 1,5 раза с 103,8 тыс. (в 1940 г.) до 152,7 тыс. (в 1950 г.) [24, с. 110].

Медленные темпы строительства объясняются недостаточным финансированием. Причем, как правило, поступали незначительные суммы, а иногда финансирование отсутствовало и вовсе. Катастрофическое положение с транспортной ситуацией в растущем Ульяновске вынудило председателя исполкома областного Совета М. Чернышева обратиться с докладной запиской к председателю Совета Министров И.В. Сталину, в которой он описывал все тяготы трамвайного строительства на родине Ильича [6, л. 31$]$.

После данного обращения уже в середине 1950 г. Министерством коммунального хозяйства РСФСР для строительства трамвая в г. Ульяновске было выделено 4,5 тыс. шпал [6, л. 31].

Помимо недостаточного финансирования и нехватки рабочей силы существовала и другая причина затянувшегося строительства, а именно некачественная работа строительных организаций. Например, директор строительства трамвая и главный инженер, изучив техническую литературу и ознакомившись с передовым опытом других городов, предложили «Ульяновскстрою» следующий способ пропитки шпал: антисептическая масса в специальной ванне нагревалась и поддерживалась всё время при температуре $60-80^{\circ}$, а затем в эту массу опускалась шпала на 2-3 минуты для впитывания её в древесину. Строительная организация, в свою очередь, производила не пропитку, а обмазку шпал. При минусовой температуре такая обмазка отлетала, а древесина начинала загнивать. Приходилось либо повторно пропитывать шпалы, либо полностью их заменять [21, л. 29].

В 1950 г. продолжилась прокладка трамвайного пути, но параллельно шло и укрепление основания. Так, в июне на Железнодорожной, Карамзинской и Кировской улицах на всём протяжении проектируемой трамвайной линии шла балластировка пути. На Железнодорожной улице к этому времени полотно уже забалластировали и заканчивали подъём и рихтовку пути. На данный участок подвезли около 3 тыс. кубометров балласта [25, с. 4].

Новое строительство было объявлено народной стройкой, по выходным к рабочим двух трестовподрядчиков, ведущих строительство, подключалась общественность и работники многих предприятий города. Только на земляных работах жители города отработали 9,7 тыс. человеко-часов [26, л. 119]. Вот как об этом вспоминал один из участников стройки Ф. Резник: «Тогда я работал мастером подъемочного ремонта локомотивного депо. И вот нам говорят: 
«Завтра, в субботу, рабочий день на строительстве трамвайных линий. Вашему цеху поручается выкопать ямы под опоры контактной сети от Южного рынка до Корсунской». Располагались они через каждые 50 метров. Бура не было, копали вручную отверстия в земле глубиной два метра, шириной один метр» [7, с. 13].

Несмотря на энтузиазм трудового народа, работы по строительству трамвая задерживались. Связано это было с тем, что «Ульяновскстрой» не всегда ответственно относился к выполнению плановых показателей. В связи с этим решением от 24 августа 1950 г. исполком Ульяновского горсовета обязал директора строящегося трамвая «обратить серьёзное внимание на качество работ по строительству, предъявляя жёсткие требования при приёмке работ от подрядчика» $[27$, с. 2].

Но для того чтобы соединить трамвайным сообщением центр города с районом автомобильного завода, как уже упоминалось выше, существовала необходимость построить капитальный мост, по которому и должны были курсировать вагоны. Строительство этого моста рассчитывалось на три года. В 1950 г. начались подготовительные работы к строительству дамбы. Устройство дамбы осуществлялось мощным гидромонитором, который намывал в сутки до одной тысячи кубометров грунта [28, с. 3]. Строители при помощи бульдозера между правым берегом реки и обрывом сделали земляное «корыто». Длина его более 200 м, ширина 40-50 м и глубина 3-5 м. Это основание дамбы, оно и заполнялось грунтом с помощью этого гидромонитора. Эти работы проводились до тех пор, пока высота дамбы не достигла 18 м [29, с. 4].

Масштабные работы по строительству и обустройству трассы развернулись к началу 1951 г. В 1952 г. устраивались кюветы от железнодорожного вокзала до электростанции, мостились камнем полотно и проезжая часть улиц. За этот год осуществлена укладка пути по ул. Ленина, Советской и Радищева. В северной части города усилилось строительство трамвайного депо, вагоноремонтных мастерских, котельной и центрального склада [4, с. 21].

Трамвайная линия полностью была построена в конце 1953 г., а начала эксплуатироваться с января 1954 г. по маршруту № 1 «Вокзал Ульяновск-I трампарк» (рис. 1) [30, с. 206].

Об открытии трамвайного движения в Ульяновске вспоминала одна из первых вагоновожатых Р.С. Разумовская (рис. 2). «В ночь с 4 на 5 января 1954 г. трамвайное депо Ульяновска готовилось к пуску первых трамваев. Зима выдалась снежная и морозная. Столбик термометра опускался до сорока градусов, сугробы доходили до вторых этажей домов. Три новеньких трамвая поручили вывести на линию тем, кто окончил курсы с отличием. Без устали работал единственный снегоочиститель. А утром В. Спирина и В. Горюнова не смогли вывести на линию вагоны, так как они замёрзли. С большим трудом удалось разогреть мой трамвай. Первый маршрут соединил Северное депо с железнодорожным вокзалом. Семь километров пути предполагалось преодолевать за час. Иду как в туннеле. Снег! Издали можно было видеть только трамвайную дугу. Страшно было. И помню горожан, стоявших по обо- чинам пути. Многие видели трамвай первый раз в жизни. Всё-таки это был праздник - люди радовались! Хотя некоторые горожане встречали появление первого вагона на линии нечленораздельными воплями. Богобоязненные бабушки при появлении трамвая кричали: «Бесы! Бесы едут!» [7, с. 13].

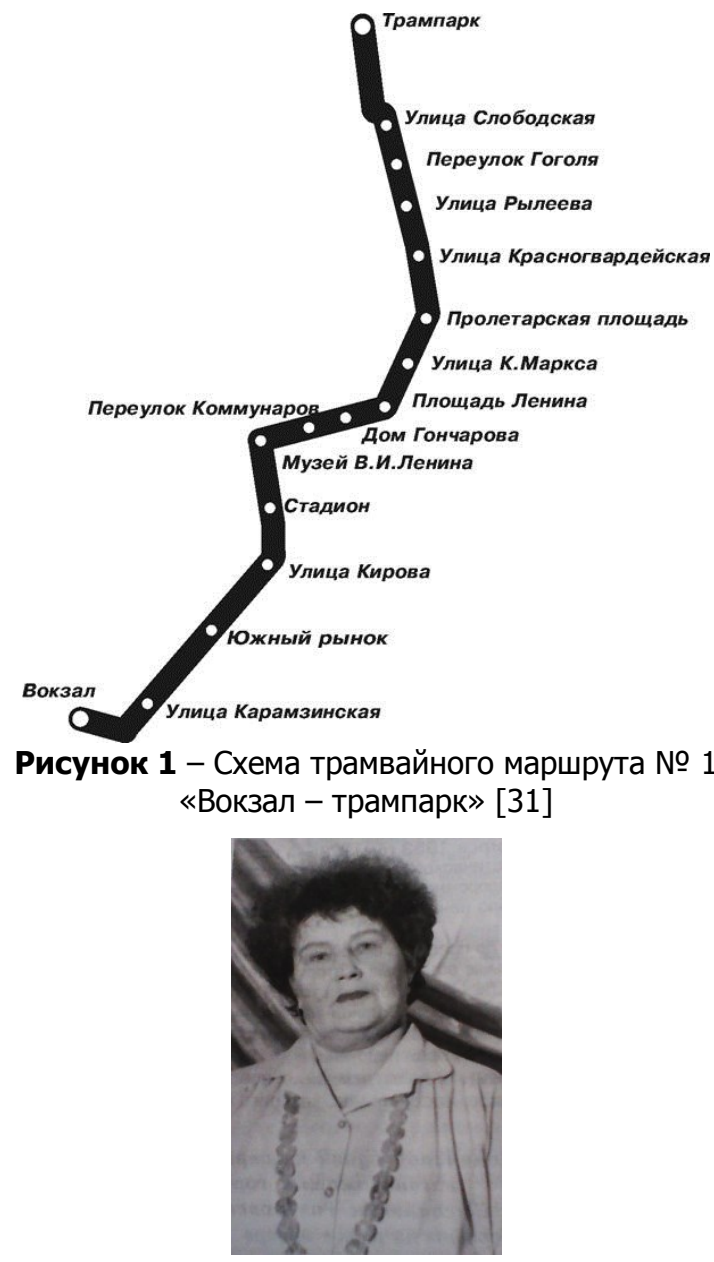

Рисунок 2 - Р.С. Разумовская - одна из первых вагоновожатых ульяновского трамвая [4, с. 24]

В первую зиму эксплуатации трамвая не обошлось и без трагедий, о чём вспоминает Р.С. Разумовская. «Прошли десятки лет, и сейчас мы удивляемся, как смогли выстоять в ту лютую зиму. Придумывали разные ухищрения. На конечной станции в депо клали кирпич в печурку, нагревали его и в вагон, себе под ноги. Когда вернёшься, сменишь кирпич. Вагоновожатая Лида Болтачева однажды поехала без такого кирпича и отморозила себе ноги» [32, с. 2].

В таких трудных условиях пришлось работать первым вагоновожатым, среди которых были ещё А.А. Григоров, Т.Я. Чичерова, Н.А. Куканова [33, с. 2].

К началу эксплуатации трамвая в январе 1954 г. материально-техническая база трамвайного управления включала в себя 13,8 км эксплуатационного одиночного пути и контактной сети, одну тяговую подстанцию, депо вместимостью 80 вагонов в северной части города, 14 трамвайных вагонов (рис. 3) типа «КТМ/КТП-1» (7 моторных и 7 прицепных), 1 снегоочиститель. Эксплуатацию и обслуживание трамвая осуществляли 28 вагоновожатых третьего класса, 4 дежурных тяговых подстанций, 10 слесарей-электриков, 6 слесарей механического и электрического оборудования, 2 монтёра по ремонту электрооборудования и 4 монтёра контактной сети [32, с. 2]. 


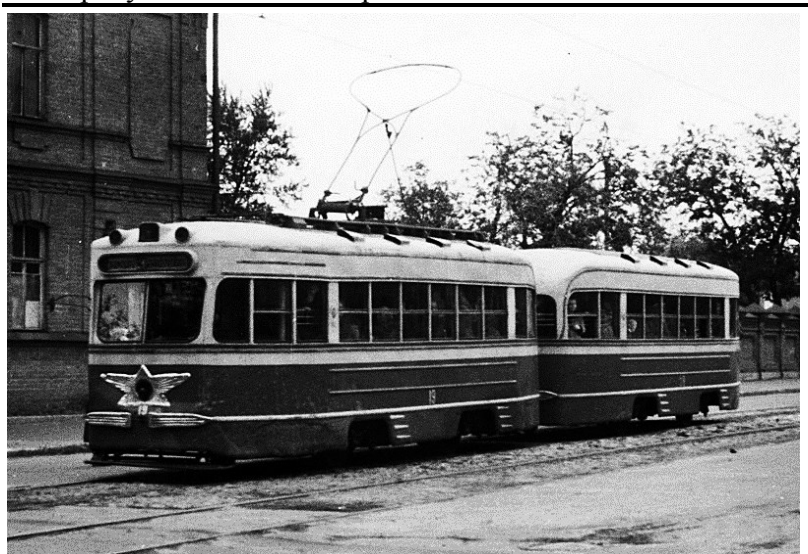

Рисунок 3 - Трамвай на ул. Железной дивизии (сер. 1950-х гг.)

Выводы исследования. Становление ульяновского трамвая прошло долгий и тернистый путь. Впервые возникшая идея строительства трамвая в городе в начале XX в. воплотилась в разработанном плане, который в силу начала Первой мировой войны реализован не был. После окончания войны данный проект был переработан, но из-за экономического кризиса и снижения административного статуса города также не воплотился в жизнь. К идее строительства вернулись лишь в 1943 г., когда город стал центром созданной Ульяновской области. Строительство трамвайной линии в Ульяновске, включая вопросы согласования трассы и составления проектов, заняло 10 лет. Только благодаря настойчивости местного руководства и участию общественности, трамвайное сообщение всё же было налажено и привело к хозяйственному освоению и развитию города.

\section{СПИСОК ЛИТЕРАТУРЫ:}

1. Голенко Е.И. Ульяновск. М.: Госстройиздат, 1956. $102 \mathrm{c}$.

2. Сивопляс И.Э. Ульяновский автобус: как всё начиналось // Ульяновская правда. 2001. 25 сен. С. 4.

3. Бармин А.В., Карпенко С.Я. Дорога длиною в пятьдесят лет: документальный очерк. Ульяновск: Ульяновскавтотранс, 1993. 112 с.

4. Царькова Е.В. Вехи пути. Исторический очерк, посвящённый 50-летию открытия трамвайного движения в Ульяновске. Ульяновск: АртКом, 2003. $159 \mathrm{c}$.

5. Доклад Городской Думе по вопросу об устройстве в г. Симбирске электрических - элеватора, трамвая и освещения. Симбирск: Типо-литография А.Т. Токарева, 1901. 64 с.
6. Государственный архив Ульяновской области (далее - ГАУО). Ф. Р-634. Оп. 1. Д. 2116.

7. Крапивина Я. 60 лет трамваю, 40 лет - троллейбусу // Ульяновская правда. 2014. 10 января. С. 13.

8. Бросман А.И., Медведев Н.Н. Ульяновск. М.: Стройиздат, $1973.96 \mathrm{c.}$

9. Ефимов Ю.Д., Лосева В.И. Ульяновск и Ульяновская область в годы Великой Отечественной войны // Ульяновцы - Великой победе. Краеведческие записки. Вып. 11. Ульяновск, 2005. С. 7-40.

10. Филиал Российского государственного архива научно-технической документации (далее - филиал РГАНТД). Ф. Р-892. Оп. 2-6. Д. 4.

11. Государственный архив Российской Федерации (далее - ГАРФ). Ф. Р-5446. Оп. 1. Д. 237.

12. Государственный архив новейшей истории Ульяновской области (далее - ГАНИУО). Ф. 13. Оп. 1. Д. 2096.

13. ГАРФ. Ф. Р-5446. Оп. 46. Д. 3612.

14. ГАНИУО. Ф. 13. Оп. 1. Д. 2303.

15. Филиал РГАНТД. Ф. Р-852. Оп. 2-6. Д. 8.

16. ГАРФ. Ф. А-314. Оп. 2. Д. 27.

17. ГАРФ. Ф. А-314. Оп. 2. Д. 454.

18. ГАРФ. Ф. А-259. Оп. 6. Д. 5716.

19. Российский государственный архив экономики. Ф. 9510. Оп. 3. Д. 145

20. ГАНИУО. Ф. 13. Оп. 1. Д. 2486.

21. ГАУО. Ф. Р-535. ОП. 5. Д. 101.

22. Ульяновская правда. 1949. 16 ноября.

23. ГАРФ. Ф. А-314. Оп. 2. Д 5799.

24. Родина В.И. Ленина. Экономико-статистический сборник. М.: Статистика, 1970. 183 с.

25. Ульяновская правда. 1950. 12 июня.

26. ГАУО. Ф. Р-535. ОП. 5. Д. 99.

27. Ульяновская правда. 1950. 9 сентября.

28. Ульяновская правда. 1950. 12 августа.

29. Ульяновская правда 1950. 25 октября.

30. Наш край (1941-1975). Документы и материалы / Госархив Ульяновской области, Партархив Ульяновского обкома КПСС. Ульяновск: Приволж. кн. изд-во, 1978. 215 с.

31. Краткая история ульяновского электротранспорта [Электронный ресурс] // Интернет-сайт МУП «Ульяновскавтотранс».

http://уэт73.pф/info/kr ist tram.html.

32. Транспортник (Ульяновск). 1985. № 1.2 января.

33. Транспортник (Ульяновск). 1985. № 28. 10 июля.

\section{THE QUESTION OF TRAM TRAFFIC DEVELOPMENT IN ULYANOVSK}

(C) 2017

Gorshenin Aleksandr Vladimirovich, senior lecturer of Humanities Department Medical University «Reaviz» (Samara, Russian Federation)

Abstract. The paper discusses the process of public transport development in Ulyanovsk. Special attention is paid to the tram construction projects that existed in the pre-revolutionary period and conditions they were implemented under. This paper examines the connection between the administrative status of the city and the public transport development. In 1920s Ulyanovsk lost the provincial center status and attempts to organize the city's line of electric vehicles were postponed for a long time. Only during the Great Patriotic war, when Ulyanovsk became the center of a newly formed region, the authorities decided to create the city tram. Considering the stages of tram transport development the author tries to identify the causes of construction work delay. The main ones were the following: inadequate funding, prolonged execution of all necessary documentation, lack of material-technical base and skilled workers. This paper examines actions undertaken to address these problems. 
The source of the study consists of unpublished documents from the funds of Federal and regional archives: the State archive of the Russian Federation, Russian state archive of Economy, branch of Russian state archive for scientific-technical documentation in the Ulyanovsk Region, State archive of contemporary history of the Ulyanovsk Region. The author also uses articles of the regional newspaper called Ulyanovskaya pravda.

Keywords: urban transport; public transport; electric transport; tram; urban economy; public utilities; traffic; Ulyanovsk; Simbirsk; Economics; history; regional history; history of everyday life; Great Patriotic war; post-war period.

УДК 93/94

\section{БЫТ РАБОЧИХ СРЕДНЕ-ВОЛЖСКОГО КРАЯ В ГОДЫ ИНДУСТРИАЛИЗАЦИИ} (C) 2017

Токмакова Лидия Петровна, кандидат исторических наук, доцент кафедры отечественной истории и археологии

Самарский государственный сочиально-педагогический университет (2. Самара, Российская Федераџия)

Аннотация. История повседневной жизни рабочих в период индустриализации, когда происходила ломка старых жизненных устоев и формирование нового быта, представляет большой интерес при изучении социальной истории Среднего Поволжья. Изучение быта рабочих промышленных предприятий крупных городов Средне-Волжского края позволяет лучше понять развитие в столь сложный период советского общества в целом. В то же время история быта рабочих данного региона обладает рядом особенностей по сравнению с промышленными центрами страны. В данной статье рассматривается наиболее болезненный вопрос периода урбанизации Среднего Поволжья в 1930-е гг. - жилищный. Его анализ невозможен без изучения истории развития городского транспорта, санитарно-гигиенического обслуживания населения, благоустройства городов. Изучение истории быта отдельного региона наглядно демонстрирует все проблемы и трудности развития рабочего класса и в целом страны в 20-30 гг. ХХ века. Этим взаимосвязанным проблемам посвящена данная работа.

Ключевые слова: уровень жизни; индустриализация; быт; кризис жилплощади; уплотнение; выселение; текучесть рабочей силы; жилищно-коммунальное строительство; общежития; дефицит стройматериалов; коммунальное хозяйство; санитарное состояние и гигиена; эпидемия; городской транспорт; благоустройство городов; субботники.

Быт - это уклад повседневной жизни человека, внепроизводственная сфера, включающая как удовлетворение материальных потребностей людей (в пище, одежде, жилище, поддержании здоровья), так и освоение духовных благ, культуры, общение, отдых, развлечение (общественный, национальный, городской, сельский, семейный, индивидуальный быт). Быт складывается и изменяется под влиянием материального производства, общественных отношений, уровня культуры, а также географических условий и оказывает огромное влияние на другие стороны жизни людей, на формирование личности. Это определение термина «быт», данное в энциклопедическом словаре, показывает важность изучения повседневной жизни человека для понимания той или иной эпохи.

В советской исторической науке теме быта разных слоёв населения уделялось крайне мало внимания. Наиболее последовательно тема быта была исследована историками, изучающих средневековье и период новой истории. В советский период истории быт был лишь иллюстрацией выдающихся достижений советской экономики. Миф о высоком уровне жизни советских людей в 30-е годы подкреплялся произведениями советских писателей художественными фильмами, музыкой. Сегодня появилась возможность более объективного исследования этой темы. Время индустриализации наиболее интересно для историка, изучающего формирование нового менталитета и нового образа жизни советских людей. В данной статье автор ставит перед собой задачу изучения только двух аспектов столь сложного понятия как «быт» в Среднем Поволжье.

Среднее Поволжье до начала индустриализации было аграрным районом с весьма слаборазвитой промышленностью. В СССР было всего три промышленных центра: Ленинград, Москва и Урал, так что экономическое развитие Среднего Поволжья было типичным для того времени. В 1916 г. в Самарской, Симбирской и Пензенской губерниях городское население составляло 7,5\%, сельское - 92,5\%.

Годы Первой мировой и Гражданской войн нанесли экономике Среднего Поволжья колоссальный ущерб. Так, в 1922 г. в Самарской губернии осталось действующими 42 предприятия с числом рабочих немногим более 3000 человек. Трубочный завод и ряд других крупных предприятий практически были закрыты. Вследствие этих обстоятельств восстановительный период занял более продолжительный срок. В 1925 г. промышленное производство достигло 70\% довоенного уровня, в 1927 г. - 80,5\% и только в 1928 г. $-118 \%$ [1].

В регионе ощущалась крайняя недостаточность инженерно-технических кадров и опытных хозяйственных руководителей. На весь огромный СреднеВолжский край в восстановительный период насчитывалось всего несколько десятков дипломированных инженеров. Высших технических учебных заведений не было, сеть техников и профтехшкол была очень мала.

Bсе попытки руководства края ускорить промышленное развитие натыкались на противодействие Госплана и ВСНХ, считающих Среднее Поволжье аграрным краем. Ситуация изменилась после принятия постановления ЦК ВКП(б) от 15 февраля 1930 г. «Об основных хозяйственных проблемах Средне-Волжского края», предусматривающего увеличения капитальных вложений в развитие промышленности края. 